JAPANESE JOURNAL OF INFLAMMATION

EDITORIAL

\title{
Lessons from immunogenetics
}

Takehiko Sasazuki

\section{免疫遺伝学に学ぶ}

\section{笹 月 健 彦*}

細菌やウイルスなど，各種の外来抗原に対する免疫応答性に個人差があることは，古く から知られていたが，1960年代後半に，アメリカの McDevitt や Benacceraf は，このよ らな免疫応答を支配する免疫応答遺伝子 (immune response gene, Ir-gene) をマウスとモ ルモットに拈いて発見した。

マウスの Ir-gene は，H-2 と連鎖していることから，この発見の当初よりヒトにおい ても当然 HLA と連鎖した Ir-gene が存在し，種々の疾病の発現に重要な役割を演じて いるであろうと推測されてきた。 特に，HLA の特定のタイプと数々の自己免疫疾患との 統計学的相関が報告されるに及んで, HLA と連鎖した Ir-gene の存在は疑いないものと して受け入れられた. しかし, 当時は遺伝学的にも免疫学的にも, ヒトに拈ける Ir-gene の存在をきちんと証明した者はなく, “HLA と疾患との相関を説明する Ir-gene”に対し て, “HLA-linked Ir-gene——unproved hypothesis”という警鐘が Science に発表され, その果たした役割は大きい.

筆者らは, 遺伝学と免疫学の両面から, この課題に取り組又, ヒトにおいては免疫応答 遺伝子ではなく，免疫抑制遺伝子 (immune suppression gene, Is-gene) が外来抗原に対す る免疫応答を制御していることを見いだした。

免疫応答機構が存在しなければ, 個体は必ず感染症で獘れることは, 先天性免疫不全症 や後天性免疫不全症 (AIDS) などの例をみるまでもなく明白である。すなわち，免疫機構 なしには人類までの進化もありえなかったことになる．個体と種の保存に必須の防御機構 として免疫機構が機能していることは, 逆に, いかなる細菌, ウイルス, 寄生虫が侵入し ても, これらに特異的に反応しらるいちじるしく高度の多様性 (diversity)を免疫系は, 獲 得していることを意味する。 この高度の多様性の基礎として, 免疫グロブリン遺伝子や T 細胞レセプター遺伝子にみられる分化に伴う遺伝子の再構築 (rearrangement) という機構 が存在する.

しかしながら, 一方では, この多様性を最大限に発揮し, いかなる外来侵入物に対して も，常に免疫応答すればよいかといらと，必ずしもそうではなく，免疫応答したがゆ党 に, 個体が各種免疫異常症を発現し, 獘れるという例は数多く知られている. そこで, こ の多様性に制約を加え，乙かもその制約には個体差，つまり高度の多型性(polymorphism) を付加することによって，種全体として眺めたときには，必ず特定の抗原に対して免疫応 答出来る個体が存在するし，また，逆に必ず免疫応答しない個体が存在することにより， 種が保存されるという機構が 必要である。この高度の多型性の分子的基盤を担うのが HLA であり，細胞レベルでは，この HLA に拘束された $\mathrm{T}$ 細胞の存在意義がここに存す ることになる．抗体は抗原単独を認識して反応するのに対し， T 細胞レセプターは, HLA

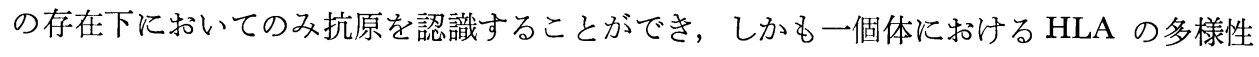

* Medical Institute of Bioregulation, Kyushu University (Department of Genetics)

九州大学生体防御医学研究所 (遺伝学部門) 
は, 免疫グロブリンの $10^{8}$ ともいわれる多様性にくらべて, $10^{2}$ 以下でくらぶべくもない. このよらな HLA の個に和ける限られた多様性と, 種に括ける高度の多様性こそが, 免疫 応答を真に意味あらしめていることになる。

免疫系に括いては，常に多様性といらことが注目され，これがもちろん免疫系の依って 立つところであるが，個に和ける“限られた多様性”と，しかもそれが一人一人異なると いう“高度の多型性”之をあわせ持った巧みな防御機構としての免疫機構を眺めるとき， 種々の病原体とのきびしい戦いといらながい淘汰の歴史をくぐりぬけてきた生物の深奥を 垣間見るような小さな感動を覚觉ずにはいられない。 